Article

\title{
Assessment of the Influence of Selected Technological Parameters on the Morphology Parameters of the Cutting Surfaces of the Hardox 500 Material Cut by Abrasive Water Jet Technology
}

\author{
Tibor Krenicky ${ }^{1, * \mathbb{D}}$, Stefania Olejarova ${ }^{1}$ and Milos Servatka ${ }^{2}$ \\ 1 Department of Technical Systems Design and Monitoring, Faculty of Manufacturing Technologies with a Seat \\ in Presov, Technical University of Kosice, Sturova 31, 08001 Presov, Slovakia; stefania.olejrova@tuke.sk \\ 2 IMSLOV, P. Horova 19, 08001 Presov, Slovakia; ms@imslov.sk \\ * Correspondence: tibor.krenicky@tuke.sk
}

check for

updates

Citation: Krenicky, T.; Olejarova, S.; Servatka, M. Assessment of the Influence of Selected Technological Parameters on the Morphology Parameters of the Cutting Surfaces of the Hardox 500 Material Cut by Abrasive Water Jet Technology. Materials 2022, 15, 1381. https:// doi.org/10.3390/ma15041381

Academic Editors: Victor Songmen and Szymon Wojciechowski

Received: 31 December 2021 Accepted: 10 February 2022 Published: 13 February 2022

Publisher's Note: MDPI stays neutral with regard to jurisdictional claims in published maps and institutional affiliations.

Copyright: (C) 2022 by the authors. Licensee MDPI, Basel, Switzerland. This article is an open access article distributed under the terms and conditions of the Creative Commons Attribution (CC BY) license (https:// creativecommons.org/licenses/by/ $4.0 /)$.

\begin{abstract}
This article deals with the evaluation of selected aspects of abrasive water jet technology (AWJ) in the cutting of abrasion-resistant steel (HARDOX 500) with a thickness of $40 \mathrm{~mm}$. The high abrasion resistance as a typical significant property of this steel ranks it among the special materials that are increasingly used. As the AWJ is a multiparametric technology, selected levels of feed rate, abrasive mass flow and pump working pressure were used in the experiments from the spectrum of technological parameters. For the purposes of evaluation, the examined cut surfaces were documented by a modified photographic method of displaying the cut surface by means of side lighting on the untreated cutting surface. The experimental part evaluates the dependences of selected cutting surface quality parameters (surface roughness and abrasive water jet deflection) on selected important technological parameters of the production system with AWJ technology (abrasive mass flow, technological head feed rate and pump working pressure). Based on the evaluation of the experiments, regression models were created to interpolate and extrapolate data to compare or supplement existing solutions in the field of research and as a basis for optimizing operating costs and increasing the efficiency of production systems with abrasive water jet technology.
\end{abstract}

Keywords: abrasive water jet; material cutting; surface quality; cut profile; regression model; Hardox; technological head feed rate; mass flow of abrasive

\section{Introduction}

Abrasive water jet technology (AWJ) is a progressive tool used to machine a wide range of materials. Profiting from its several unique features, such as cold machining of hardto-machine materials without their deformation, separation of inhomogeneous materials and a small amount of waste material, AWJ has a significant potential to replace other machining techniques in several applications [1]. The pioneer scientists dealing with the topic were Hashish [2] and Zeng and Kim [3]. Later, numerous investigations aimed at the machining process appeared, e.g., by Kovacevic and Yong [4,5]. The current state of research of abrasive water jet technology revealed that one of the most important problems is the quantification and modeling of the influence of technological parameters on surface quality parameters, particularly at hard-to-machine materials sheets by Savkovic [6]. Abrasive water-jet cutting is a multiparametric process where the quality of the output characteristics relies on the inputs. This has been proven by various experiments and theoretical analyses. Evaluation of cutting quantity and quality has been continuously studied by various groups [7-10]. Sutowska et al. [11] studied the influence of cutting parameters on kerf quality in detail. Some of the recent experiments were performed on $\operatorname{Hardox}^{\mathrm{TM}} 400,450$ and 500 steel sheets by Filip et al. $[12,13]$. Yet there are numerous attempts at creating the 
models that characterize the cut area quality under specific conditions regarding material type and thickness, technological head feed rate, the abrasive mass flow rate, grain size and many others. Evaluation of the cutting quality is related to the quality of the cut walls. Although there is a constantly growing set of developed solutions to the problem, including methodologies and evaluations of experiments valid for specific measurement conditions, the current solutions still do not cover several variations.

Models of machining materials using AWJ technology describe the action of a concentrated water jet, the efficiency of which is often increased by doping with solid abrasive particles such as garnet [14]. The model proposed by Monno and Ravasio [15] is based on the assessment of the striation formation that depends mainly on the jet instability caused by vibrations during the cutting process. Similar to other high-energy beam technologies, the AWJ jet generates visible striations on the machined surface [16-20]. The quality of the cutting process is the result of the tool's operation as part of the overall effect on the overall quality of the product, conditioned by three types of accuracy: shape, dimensional and surface measure, characterized mainly by roughness parameters [21]. The roughness of the machined surface using AWJ deteriorates from the point of entry into the material to the point of exit. The striating is generated at a certain depth below the surface and gradually deepens, causing a negative effect on the quality of the machined surfaces as well as on the shape accuracy of the products. The machined surface is thus divided into a smooth zone and a rough-striated zone. This behavior arises from the fact that since the jet penetrates the material, it gradually loses its kinetic energy and deflects. The relatively smooth area in the upper part of the cut is identified as the zone of cutting wear of the material, while the second striated area in the lower part of the cut arises as a consequence of deformation wear during cutting by AWJ technology [22,23].

The most common characteristics used for the evaluation of the surface roughness are $R a$, the mean arithmetic deviation of the profile, and $R z$, the height of the profile unevenness. These two quantities can be measured by contact profilometers or by noncontact profilometers [24-26]. Nevertheless, the values depend not only on cut material or depth in the kerf but also on abrasive material quality and grain size [27]. Hlaváč́s group had presented a different approach to the determination of the cutting wall quality than the use of the $R a$ and $R z$ values, proposing a direct relationship between the declination angle (measured between the tangent to the striation curve in the definite depth $h$ and the impinging jet axis) and respective cutting wall quality $[28,29]$. Understanding the influence of machining conditions on the quality of the obtained cuts enhances the quality and effectiveness of cutting. The basic process parameters characterizing the machining of materials using AWJ include the pumping pressure; feed rate of the technological head; abrasive mass flow; diameter of the nozzle and focusing tube and distance of the technological head from the material surface [30]. The microscopic models describing the mechanism of material cutting were prepared as well as the macroscopic model of cutting front behavior [31,32].

The recent research is focused on complementing existing models and preparing some new ones that would be simple enough to be applicable in industrial conditions to help predict and control the production quality. The results presented in this paper can be used for the regression models helping predict the surface quality relationship with the cutting factors, such as water pressure, feed rate and abrasive mass flow rate. In our opinion, the study of parameters in presented combination and range are unique. Thus, the novelty of the present manuscript is based on a unique combination of the thick durable material and variated operational parameters. Our work is aimed to complement data for models present in some other research works as some readers maybe appreciate such kind of information. Authors hope that data can be useful from research as well as practical points of view. 


\section{Materials and Methods}

The experimental cutting of test specimens was performed in the Liquid Jet Laboratory, Institute of Physics, Faculty of Mining and Geology, University of Mining-Technical University of Ostrava using a production system with AWJ technology. The system includes a Flow HSQ 5X high-pressure pump and an X-Y WJ1020-1Z-EKO workbench together with an X-Y CNC control system with a PaserIII ${ }^{\mathrm{TM}}$ cutting head.

All samples were cut from Hardox ${ }^{\mathrm{TM}} 500$ abrasion-resistant plates with a nominal hardness of $500 \mathrm{HBW}$ developed for applications with high demands on abrasion resistance. Material properties were obtained by a combination of quenching and tempering performed by manufacturer SSAB Oxelösund AB, Sweden. A sheet thickness of $40 \mathrm{~mm}$ was used for the individual sets of experiments.

The samples were cut from sheet metal at combinations of feed rate $v(10 ; 15$ and $20 \mathrm{~mm} / \mathrm{min})$, abrasive mass flow $m_{A}(170 ; 220$ and $270 \mathrm{~g} / \mathrm{min})$ and pump working pressure $p$ (300; 340 and $380 \mathrm{MPa})$. The plate was placed on the grid of the $\mathrm{X}-\mathrm{Y}$ workbench, the mutually perpendicular sides of the plate being parallel to the working axes $X$ and $Y$ of the table. The distance of the nozzle of the cutting head from the material surface at all cuts was $2 \mathrm{~mm}$. The process of cutting itself consisted of 2 parts - the production of the hole in the material from which the water jet began to cut, and consequently, cutting the samples in the form of an equilateral triangle (Figure 1a). All holes were made before cutting, while the cutting head held on its body a protective sheet metal element in the shape of a cylinder closed on the top that was designed to prevent spraying the reflected jet into the space and thus polluting the laboratory with droplets of water and abrasive (Figure 1b).

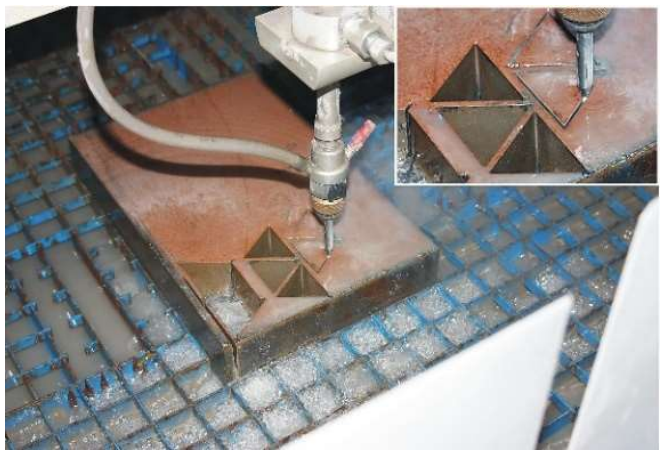

(a)

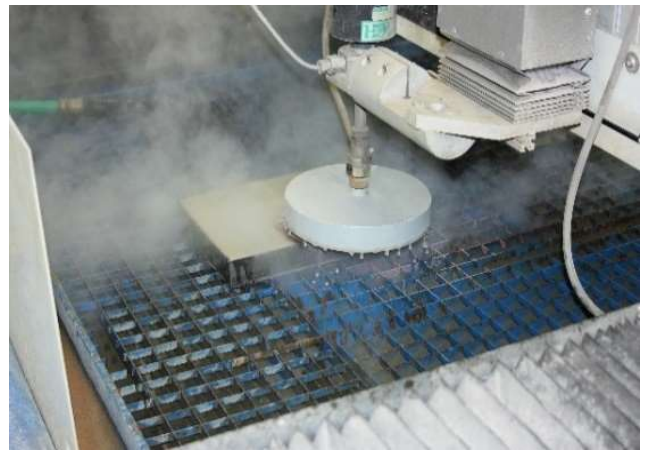

(b)

Figure 1. (a) Cutting $40 \mathrm{~mm}$ thick Hardox 500 sheet metal; (b) usage of protective cylinder.

Cutting parameters were as following:

Water orifice diameter $d_{0}-0.25 \mathrm{~mm}$

Stand-off distance $L-2 \mathrm{~mm}$

Focusing tube diameter $d_{a}-1.02 \mathrm{~mm}$

Focusing tube length $l_{a}-76 \mathrm{~mm}$

Abrasive material average grain size $a_{0}-0.275 \mathrm{~mm}$ (MESH 80)

Abrasive material-Australian garnet GMA

A total of 9 pieces of samples were cut. The total number of various cutting parameter combinations was 27 ( 3 areas on each sample). All the samples cut by abrasive water jet were marked for accurate evaluation to avoid confusion. The marking was performed immediately after cutting the set of samples and drying them on their upper surfaces (closer to the upper cutting edges). The beginning of the cut was marked with a dot on each upper surface of the sample. The arrow indicated the cutting direction and procedure. The method of labeling the samples for evaluation can be seen in Figure 2. 


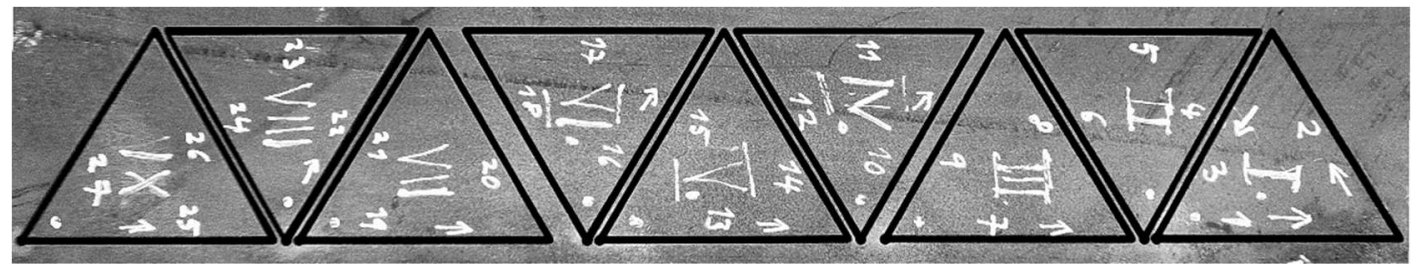

Figure 2. Example of sample marking.

The roughness parameters $R a$ and $R z$ were measured in the middle height of the sample, i.e., at half the cut material's thickness. The roughness parameters $R a_{4}$ and $R z_{4}$ were measured on the cut surfaces of samples at a distance of $4 \mathrm{~mm}$ from the upper cutting edge (from the surface of the sheet where the jet enters the material) using the Mitutoyo Surftest SJ-301 roughness tester-see Figure 3. Repeated control measurements were performed for the reliability of all measured sets of values. The control measurements' total errors for the roughness $R a, R z, R a_{4}$, and $R z_{4}$ are in the range <3.06; 5.09> percent [15].

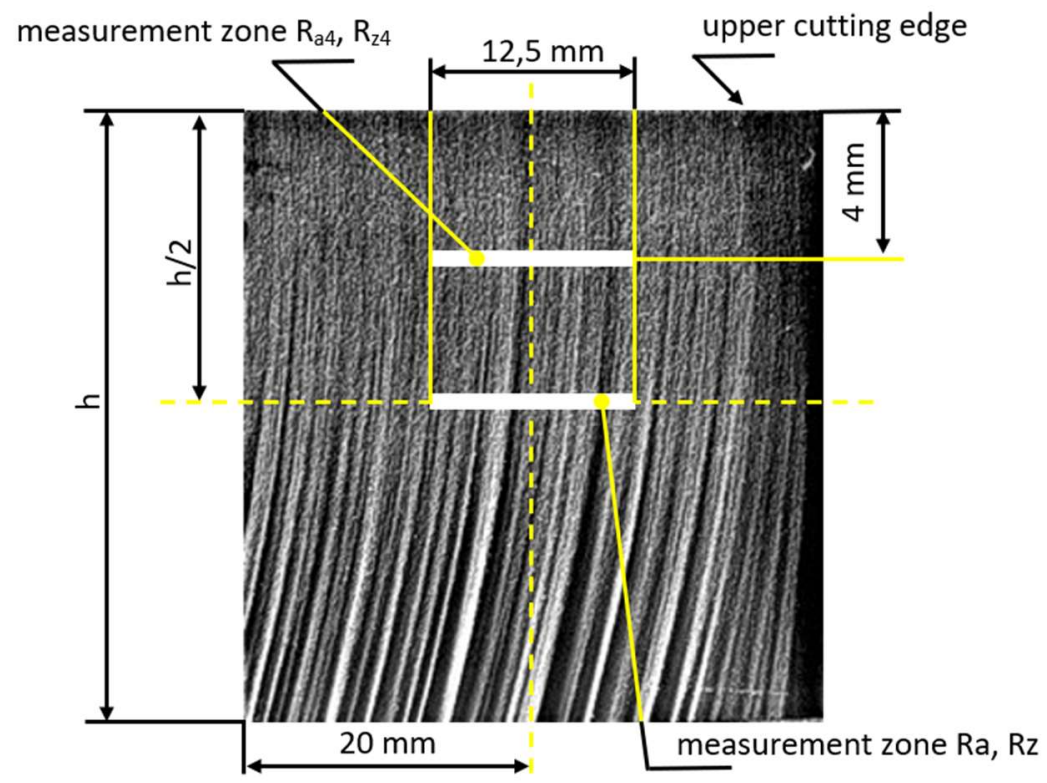

Figure 3. Roughness measuring zones for the parameters $R a, R z, R a_{4}$, and $R z_{4}$ on the cut surfaces of the samples.

The deflection of the abrasive water jet $\varnothing$ was measured at 5 locations on each cut surface, steadily at $5 \mathrm{~mm}$ distance from the previous measurement in the cutting direction according to Figure 4.

\subsection{Description of Measuring Equipment}

Roughness measurements of the cut surfaces of the samples were performed using the Mitutoyo Surftest SJ-301 roughness tester. The device was used to measure the surface roughness of the cut surfaces $\left(R a, R z, R a_{4}\right.$ and $\left.R z_{4}\right)$ of the samples. The device contains a contact probe, which measures the surface profile using a differential induction detection method and evaluates the surface quality calculating parameters according to the standards. The length of the measuring needle path in the roughness measuring device was $12.5 \mathrm{~mm}$. The detail of the measuring device when measuring the roughness of the cut surface of the sample is illustrated in Figure 5. 


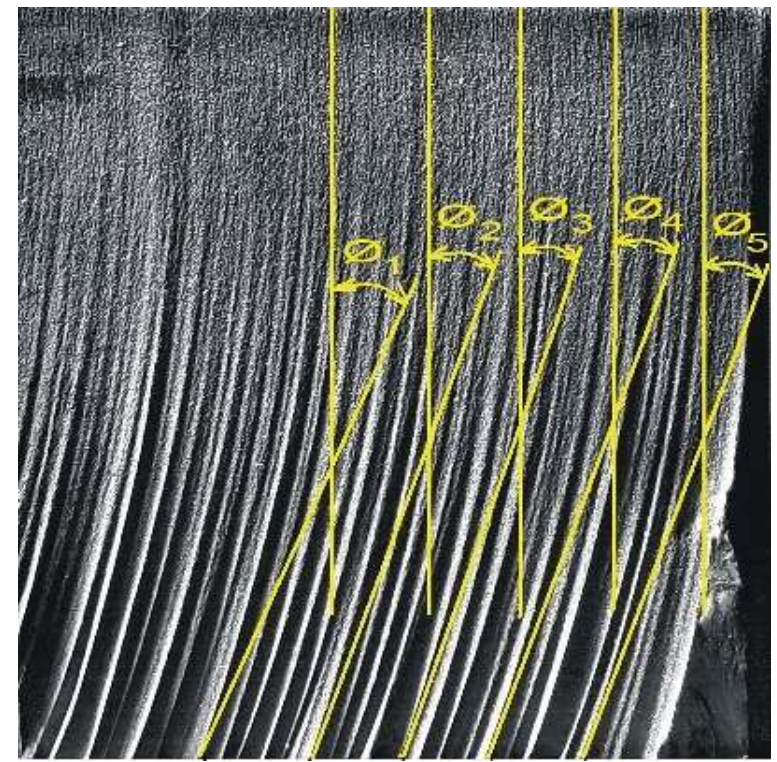

Figure 4. Localization of the measurement of the deflection of the abrasive water jet trace on the cut surface.

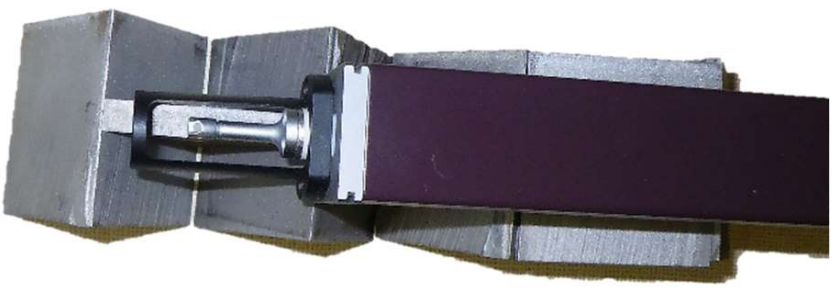

Figure 5. Surftest SJ-301 device measuring the roughness of the cut surface.

\subsection{Analysis and Evaluation of the Surface}

The analysis of the results of the experimental studies was structured into the following blocks:

- Measured values of roughness $R a, R z, R a_{4}$ and $R z_{4}$ and deflection of the jet $\varnothing$;

- Roughness measured in the middle of the cut areas of the samples;

- Roughness measured $4 \mathrm{~mm}$ from the upper cutting edges on the samples' cut surfaces;

- Deflection of the abrasive water jet;

- Evaluation based on photographic pictures of cut surfaces.

\section{Results}

3.1. Measured Values of Roughness $R a, R z, R a_{4}$ and $R z_{4}$ and Deflection of the Abrasive Water Jet $\varnothing$

Table 1 presents a set of measured values of the deflection of the abrasive water jet $\varnothing$ and the surface roughness parameters $R a$ and $R z$ measured in the centers of the cut areas of the samples according to locations depicted in Figures 3 and 4, varying with change in the selected technological parameters-feed rate of the technological head, abrasive mass flow and pumping pressure. 
Table 1. Values of the deflection of the abrasive water jet track $\varnothing$ and the roughness parameters $R a$ and $R z$ as measured on the cut surfaces of the samples.

\begin{tabular}{|c|c|c|c|c|c|c|c|c|c|c|c|c|}
\hline \multicolumn{2}{|c|}{$\begin{array}{c}\text { Sample } \\
\text { Identification }\end{array}$} & \multicolumn{3}{|c|}{ Technological Parameters } & \multicolumn{8}{|c|}{ Qualitative Parameters } \\
\hline \multirow{2}{*}{$\begin{array}{l}\text { Sample } \\
\text { No. }\end{array}$} & \multirow{2}{*}{$\begin{array}{l}\text { Sample } \\
\text { Cut No. }\end{array}$} & \multirow{2}{*}{$\begin{array}{c}m_{A} \\
{[\mathrm{~g} / \mathrm{min}]}\end{array}$} & \multirow{2}{*}{$\begin{array}{c}p \\
{[\mathrm{MPa}]}\end{array}$} & \multirow{2}{*}{$\begin{array}{c}v \\
{[\mathrm{~mm} / \mathrm{min}]}\end{array}$} & \multicolumn{5}{|c|}{ Repeated Measurements for Evaluation $\varnothing\left[{ }^{\circ}\right]$} & \multirow{2}{*}{$\varnothing\left[^{\circ}\right]$} & \multirow{2}{*}{$R a$} & \multirow{2}{*}{$R z$} \\
\hline & & & & & $\emptyset_{1}$ & $\varnothing_{2}$ & $\varnothing_{3}$ & $\varnothing_{4}$ & $\varnothing_{5}$ & & & \\
\hline \multirow{3}{*}{ I } & 1 & 170 & 300 & 10 & 17.4 & 18.1 & 17.5 & 18.0 & 17.5 & 17.7 & 3.65 & 20.84 \\
\hline & 2 & 170 & 300 & 15 & 20.8 & 28.0 & 25.2 & 25.1 & 24.2 & 24.7 & 4.09 & 21.90 \\
\hline & 3 & 170 & 300 & 20 & 34.9 & 26.8 & 28.5 & 28.0 & 32.1 & 30.1 & 6.95 & 24.96 \\
\hline \multirow{3}{*}{ II } & 4 & 170 & 340 & 10 & 15.0 & 14.2 & 15.8 & 14.2 & 15.9 & 15.0 & 2.90 & 19.79 \\
\hline & 5 & 170 & 340 & 15 & 17.5 & 19.0 & 18.2 & 17.5 & 18.6 & 18.2 & 3.92 & 21.00 \\
\hline & 6 & 170 & 340 & 20 & 22.8 & 25.4 & 30.0 & 29.5 & 23.0 & 26.1 & 5.87 & 23.64 \\
\hline \multirow{3}{*}{ III } & 7 & 170 & 380 & 10 & 14.0 & 14.8 & 14.6 & 14.8 & 14.4 & 14.5 & 2.83 & 19.11 \\
\hline & 8 & 170 & 380 & 15 & 17.4 & 16.8 & 17.0 & 17.0 & 17.3 & 17.1 & 3.66 & 20.81 \\
\hline & 9 & 170 & 380 & 20 & 22.1 & 19.7 & 21.7 & 19.4 & 22.9 & 21.2 & 4.10 & 22.90 \\
\hline \multirow{3}{*}{ IV } & 10 & 220 & 300 & 10 & 14.1 & 14.2 & 14.5 & 14.3 & 14.3 & 14.3 & 2.75 & 18.67 \\
\hline & 11 & 220 & 300 & 15 & 16.5 & 17.2 & 17.1 & 16.8 & 17.1 & 16.9 & 3.46 & 20.56 \\
\hline & 12 & 220 & 300 & 20 & 21.7 & 19.8 & 20.3 & 19.6 & 21.3 & 20.5 & 4.07 & 21.10 \\
\hline \multirow{3}{*}{ V } & 13 & 220 & 340 & 10 & 14.3 & 13.6 & 13.9 & 13.7 & 13.8 & 13.9 & 2.71 & 17.14 \\
\hline & 14 & 220 & 340 & 15 & 15.4 & 16.0 & 16.1 & 15.8 & 15.5 & 15.8 & 3.22 & 20.60 \\
\hline & 15 & 220 & 340 & 20 & 19.0 & 21.1 & 19.3 & 18.8 & 21.0 & 19.8 & 3.65 & 20.93 \\
\hline \multirow{3}{*}{ VI } & 16 & 220 & 380 & 10 & 14.0 & 13.4 & 13.1 & 14.1 & 13.0 & 13.5 & 2.60 & 16.83 \\
\hline & 17 & 220 & 380 & 15 & 15.1 & 15.7 & 15.3 & 15.4 & 15.4 & 15.4 & 3.02 & 19.66 \\
\hline & 18 & 220 & 380 & 20 & 18.1 & 19.6 & 18.6 & 18.8 & 18.7 & 18.8 & 3.46 & 20.69 \\
\hline \multirow{3}{*}{ VII } & 19 & 270 & 300 & 10 & 13.3 & 13.1 & 12.5 & 12.2 & 13.7 & 13.0 & 2.44 & 16.52 \\
\hline & 20 & 270 & 300 & 15 & 15.0 & 13.5 & 13.8 & 14.7 & 13.6 & 14.1 & 3.01 & 19.30 \\
\hline & 21 & 270 & 300 & 20 & 17.6 & 18.2 & 19.1 & 19.0 & 17.8 & 18.3 & 3.33 & 20.10 \\
\hline \multirow{3}{*}{ VIII } & 22 & 270 & 340 & 10 & 11.7 & 10.7 & 12.1 & 12.2 & 11.0 & 11.5 & 2.28 & 16.25 \\
\hline & 23 & 270 & 340 & 15 & 12.9 & 12.5 & 12.4 & 12.9 & 12.8 & 12.7 & 2.93 & 18.29 \\
\hline & 24 & 270 & 340 & 20 & 17.1 & 16.7 & 16.5 & 16.8 & 16.8 & 16.8 & 3.21 & 19.77 \\
\hline \multirow{3}{*}{ IX } & 25 & 270 & 380 & 10 & 10.2 & 9.4 & 9.3 & 9.1 & 9.8 & 9.6 & 2.27 & 16.02 \\
\hline & 26 & 270 & 380 & 15 & 10.1 & 10.4 & 11.1 & 10.4 & 10.5 & 10.5 & 2.67 & 16.77 \\
\hline & 27 & 270 & 380 & 20 & 15.2 & 14.7 & 14.1 & 13.9 & 14.9 & 14.6 & 2.96 & 18.40 \\
\hline \multicolumn{5}{|c|}{ Average values of $\emptyset, R a$ and $R z$, respectively } & & & & & & 16.8 & 3.41 & 19.72 \\
\hline
\end{tabular}

Table 2 presents a set of measured values of roughness parameters $R a_{4}$ and $R z_{4}$ of cut surfaces measured at a distance of $4 \mathrm{~mm}$ from the upper cutting edge according to Figure 3 .

Table 2. Values of the roughness parameters $R a_{4}$ and $R z_{4}$ as measured on the cut surfaces of the samples at a distance of $4 \mathrm{~mm}$.

\begin{tabular}{ccccccc}
\hline \multicolumn{2}{c}{ Sample Identification } & \multicolumn{3}{c}{ Technological Parameters } & \multicolumn{2}{c}{ Qualitative Parameters } \\
\hline $\begin{array}{c}\text { Sample } \\
\text { No. }\end{array}$ & $\begin{array}{c}\text { Sample } \\
\text { Cut No. }\end{array}$ & $\begin{array}{c}\boldsymbol{m}_{\boldsymbol{A}} \\
{[\mathbf{g} / \mathbf{m i n}]}\end{array}$ & $\boldsymbol{p}[\mathbf{M P a}]$ & $\begin{array}{c}\boldsymbol{v} \\
{[\mathbf{m m} / \mathbf{m i n}]}\end{array}$ & $\boldsymbol{R} \boldsymbol{a}_{\mathbf{4}}$ & $\boldsymbol{R} \boldsymbol{z}_{\mathbf{4}}$ \\
\hline \multirow{2}{*}{ I } & 1 & 170 & 300 & 10 & 3.03 & 18.87 \\
& 2 & 170 & 300 & 15 & 3.10 & 19.37 \\
& 3 & 170 & 300 & 20 & 3.36 & 21.69 \\
\hline \multirow{2}{*}{ II } & 4 & 170 & 340 & 10 & 2.81 & 18.44 \\
& 5 & 170 & 340 & 15 & 2.93 & 19.17 \\
& 6 & 170 & 340 & 20 & 3.10 & 21.39 \\
\multirow{2}{*}{ III } & 7 & 170 & 380 & 10 & 2.47 & 18.01 \\
& 8 & 170 & 380 & 15 & 2.83 & 19.01 \\
& 9 & 170 & 380 & 20 & 3.02 & 19.99 \\
\hline
\end{tabular}


Table 2. Cont.

\begin{tabular}{|c|c|c|c|c|c|c|}
\hline \multicolumn{2}{|c|}{ Sample Identification } & \multicolumn{3}{|c|}{ Technological Parameters } & \multicolumn{2}{|c|}{ Qualitative Parameters } \\
\hline $\begin{array}{c}\text { Sample } \\
\text { No. }\end{array}$ & $\begin{array}{l}\text { Sample } \\
\text { Cut No. }\end{array}$ & $\underset{[\mathrm{g} / \mathrm{min}]}{m_{A}}$ & $p$ [MPa] & $\begin{array}{c}v \\
{[\mathrm{~mm} / \mathrm{min}]}\end{array}$ & $R a_{4}$ & $R z_{4}$ \\
\hline \multirow{3}{*}{ IV } & 10 & 220 & 300 & 10 & 2.36 & 17.86 \\
\hline & 11 & 220 & 300 & 15 & 2.56 & 18.72 \\
\hline & 12 & 220 & 300 & 20 & 2.99 & 19.95 \\
\hline \multirow{3}{*}{$\mathrm{V}$} & 13 & 220 & 340 & 10 & 2.26 & 17.23 \\
\hline & 14 & 220 & 340 & 15 & 2.49 & 18.61 \\
\hline & 15 & 220 & 340 & 20 & 2.78 & 19.67 \\
\hline \multirow{3}{*}{ VI } & 16 & 220 & 380 & 10 & 2.16 & 16.90 \\
\hline & 17 & 220 & 380 & 15 & 2.44 & 18.09 \\
\hline & 18 & 220 & 380 & 20 & 2.71 & 19.53 \\
\hline \multirow{3}{*}{ VII } & 19 & 270 & 300 & 10 & 2.11 & 16.81 \\
\hline & 20 & 270 & 300 & 15 & 2.29 & 17.92 \\
\hline & 21 & 270 & 300 & 20 & 2.68 & 18.96 \\
\hline \multirow{3}{*}{ VIII } & 22 & 270 & 340 & 10 & 2.07 & 16.64 \\
\hline & 23 & 270 & 340 & 15 & 2.24 & 17.54 \\
\hline & 24 & 270 & 340 & 20 & 2.53 & 18.92 \\
\hline \multirow{3}{*}{ IX } & 25 & 270 & 380 & 10 & 2.02 & 16.19 \\
\hline & 26 & 270 & 380 & 15 & 2.22 & 17.23 \\
\hline & 27 & 270 & 380 & 20 & 2.50 & 18.78 \\
\hline \multicolumn{5}{|c|}{ Average values of $R_{a 4}$ and $R_{z 4}$} & 3.15 & 20.95 \\
\hline
\end{tabular}

The values are varying with change in the selected technological parameters-feed rate of the technological head, abrasive mass flow and pumping pressure.

\subsection{Roughness Measured in the Centers of the Cut Areas of the Samples}

The graphs in Figure 6 present a graphical evaluation of 1-parametric dependencies of $R a=\mathrm{f}(v)$. These dependencies are presented in the form of conjugated graphs for cases of constant abrasive mass flow (in each graph, three dependencies are plotted for the three different values of pressures of 300, 340 and $380 \mathrm{MPa}$ ).

The graphs in Figure 7 present a graphical evaluation of 1-parametric dependencies of $R z=\mathrm{f}(v)$. These dependencies are shown in the form of conjugated graphs for cases of constant abrasive mass flow (in each graph, three dependencies are plotted for the three different values of pressures 300, 340 and $380 \mathrm{MPa}$ ).

\subsection{Roughness Measured $4 \mathrm{~mm}$ from the Upper Cutting Edges of the Cut Areas of the Samples}

Graphical evaluation of the 1-parametric dependence in Figure 8 shows the dependence of the technological parameter $\mathrm{v}$ on the quality parameters of the cut surface $R a_{4}$ at a constant distance of the roughness measuring point from the upper cutting edge as presented in Figure 3. The mass flow of the abrasive is constant. In each graph, three dependencies are plotted for the three different values of pressures 300, 340 and $380 \mathrm{MPa}$.

The graphs in Figure 9 show a graphical evaluation of the 1-parametric dependencies of $R z_{4}=\mathrm{f}(\mathrm{v})$ at a constant distance of the roughness measuring point from the upper cutting edge (Figure 3). These dependencies are presented in the form of conjugated graphs for cases of the constant abrasive mass flow (in each graph, three dependencies are plotted for three different values of pressures of 300, 340 and $380 \mathrm{MPa}$ ). 

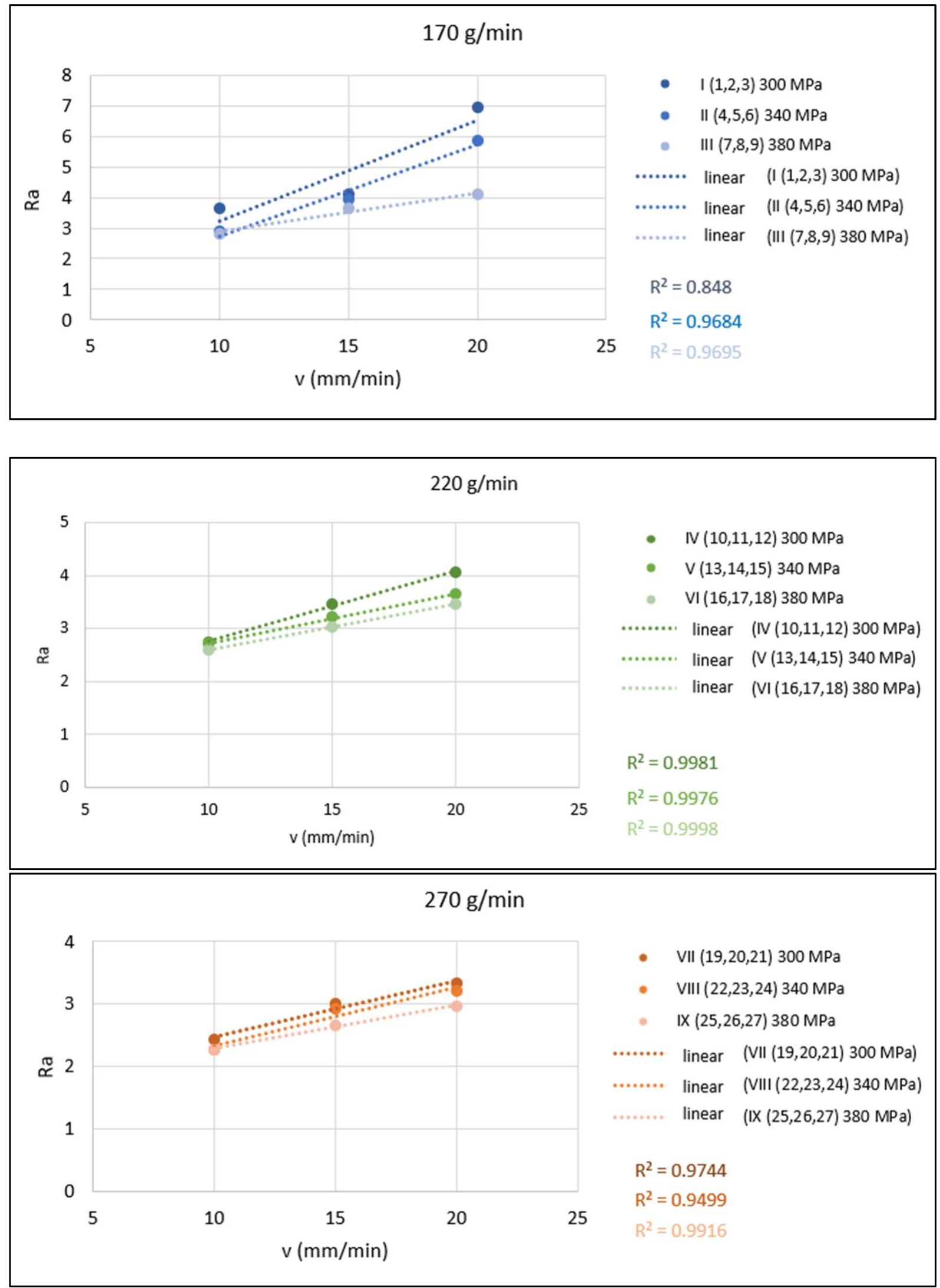

Figure 6. Graphical evaluation of 1-parametric dependences of $R a=\mathrm{f}(v)$ for $m_{A}=170,220$ and $270 \mathrm{~g} / \mathrm{min}$. 

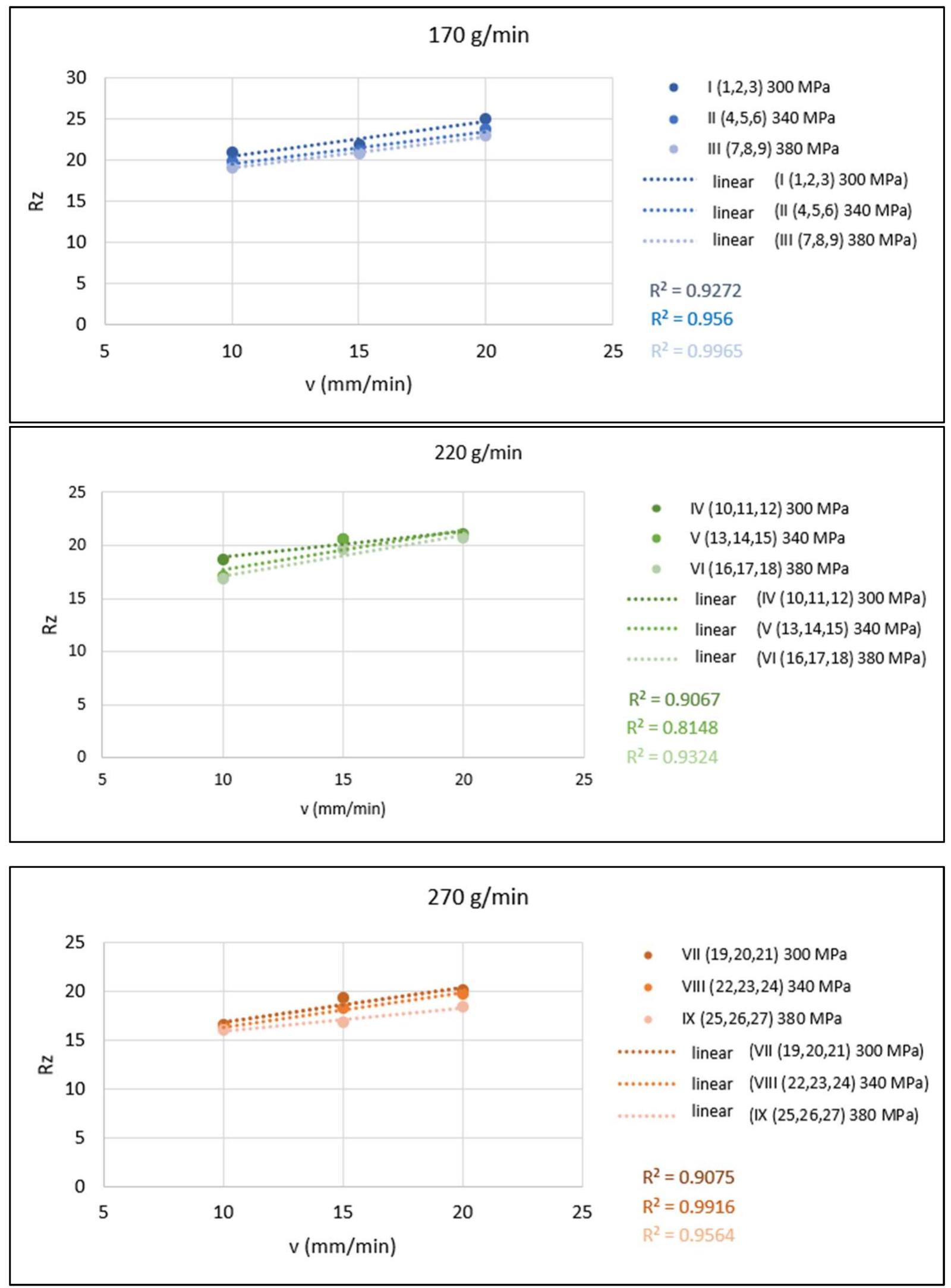

Figure 7. Graphical evaluation of 1-parametric dependencies of $R z=\mathrm{f}(v)$ for $m_{A}=170,220$ and $270 \mathrm{~g} / \mathrm{min}$. 

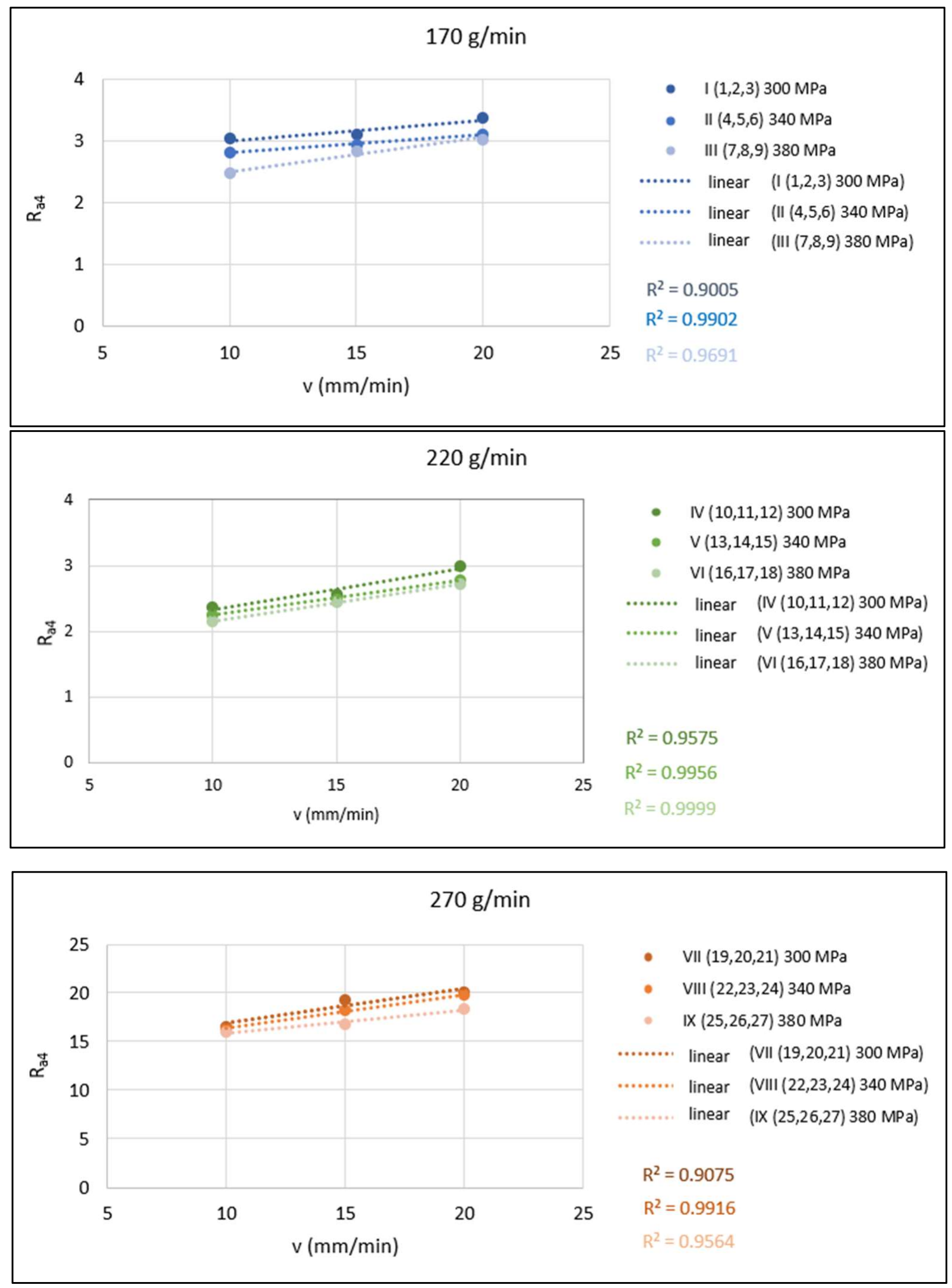

Figure 8. Graphical evaluation of 1-parametric dependencies of $R a_{4}=f(v)$ for $m_{A}=170,220$ and $270 \mathrm{~g} / \mathrm{min}$. 

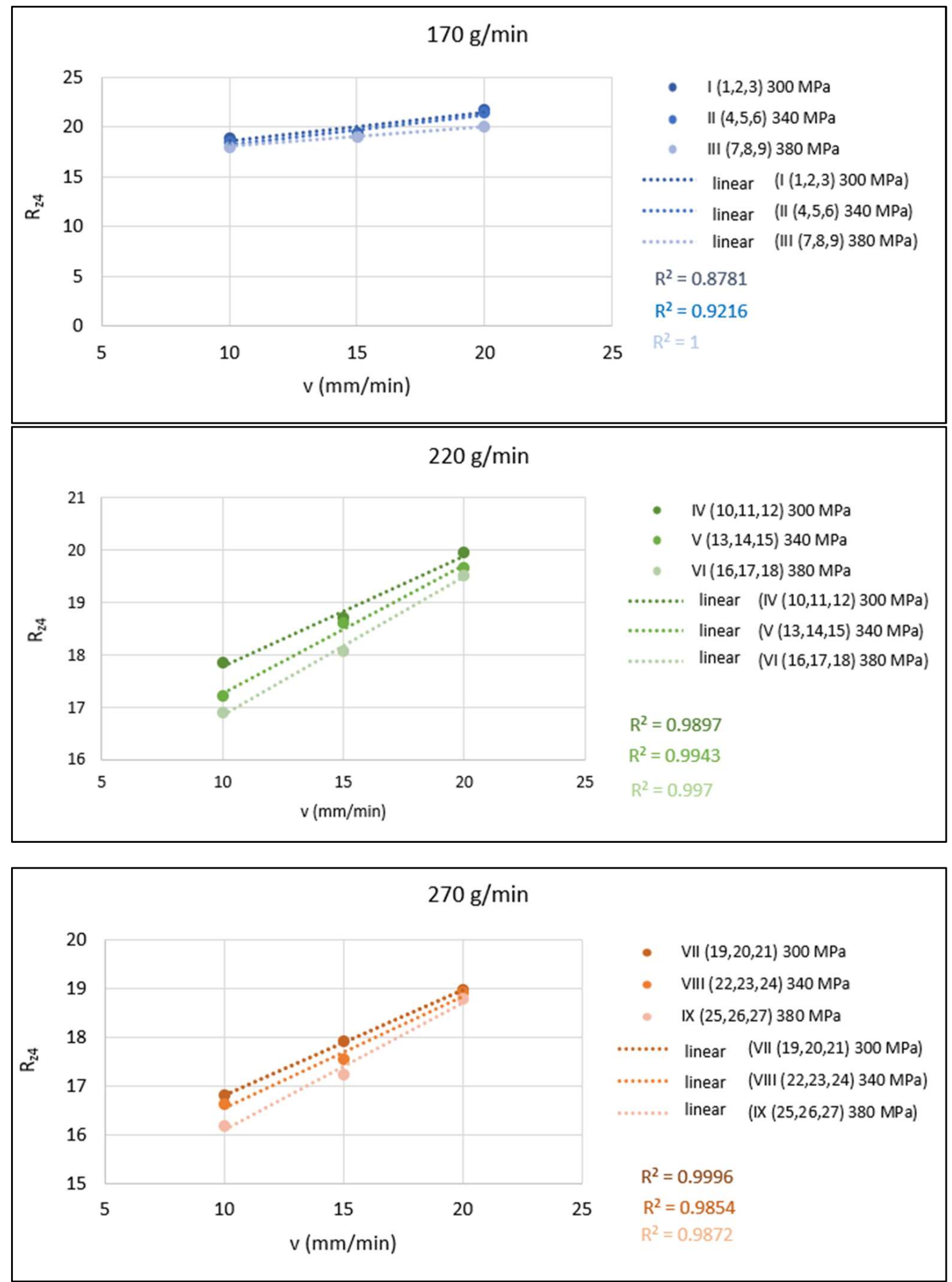

Figure 9. Graphical evaluation of 1-parametric dependencies of $R z_{4}=\mathrm{f}(v)$ for $m_{A}=170,220$ and $270 \mathrm{~g} / \mathrm{min}$.

\subsection{Evaluation Based on Photographic Images of Cut Surfaces}

The acquisition of a set of digital images from the cut areas of the examined samples was provided by a specific photographing method using side lighting to illuminate the untreated cut area, enabling jet deflection measurements. Figure 10 provides an example of four selected images of the cut surfaces taken by the above-mentioned method. 


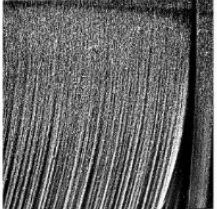

$\mathrm{U}-1 / 1$

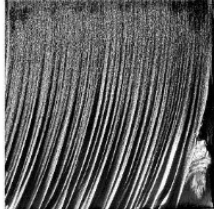

$\mathrm{U}-11 / 6$

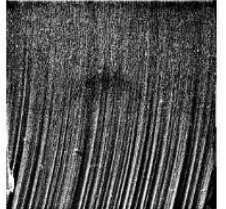

$\mathrm{U}-\mathrm{V} / 13$

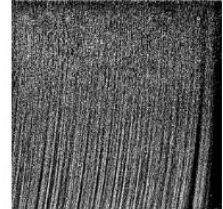

$\mathrm{U}-\mathrm{IX} / 25$

Figure 10. Photographic images of cut surfaces.

The observations made using the photographic pictures complement the previous information gained from experimental data evaluation and enable obtaining a more complete and clearer view of the specific technological parameters effect. Observing the lower parts of the cut surfaces of selected samples presented in Figure 10 (at the values of technological parameters $m_{A}$ and $p$ from their lower ranges and $v$ from the upper range), a markedly rough surface is visible, characterized by large bended striations caused by significant deflection (lagging) of the water jet and significant depth difference between the peaks and valleys of the striations.

All cut areas of the sample set show a significantly lower roughness in their upper part (closer to the cutting edge on the jet entering side) as compared with the lower part. Striations are visible on the cut surfaces of all samples. With more favorable values of technological parameters (lower $v$, higher $p$ and higher $m_{A}$ ) from the experimental set, it is possible to observe a gradual straightening of striations and simultaneously a reduction in the deflection of the abrasive water jet. The beginnings of striations are transferred with more favorable values of technological parameters from the upper part of the cut area to the lower part, as illustrated in Figure 10 U-I/1, U-V/13 and U-IX/25.

\subsection{Deflection of the Abrasive Water Jet}

The qualitative parameter deflection of the abrasive water jet $\varnothing$ on the surface of the cut surface as a dependence $\varnothing=\mathrm{f}(v)$ is shown in Figure 11. These dependencies are presented in the form of conjugated graphs for the cases where the mass flow of the abrasive is constant (in one graph, three dependencies are plotted for three different values of pressures 300,340 and $380 \mathrm{MPa}$ ).

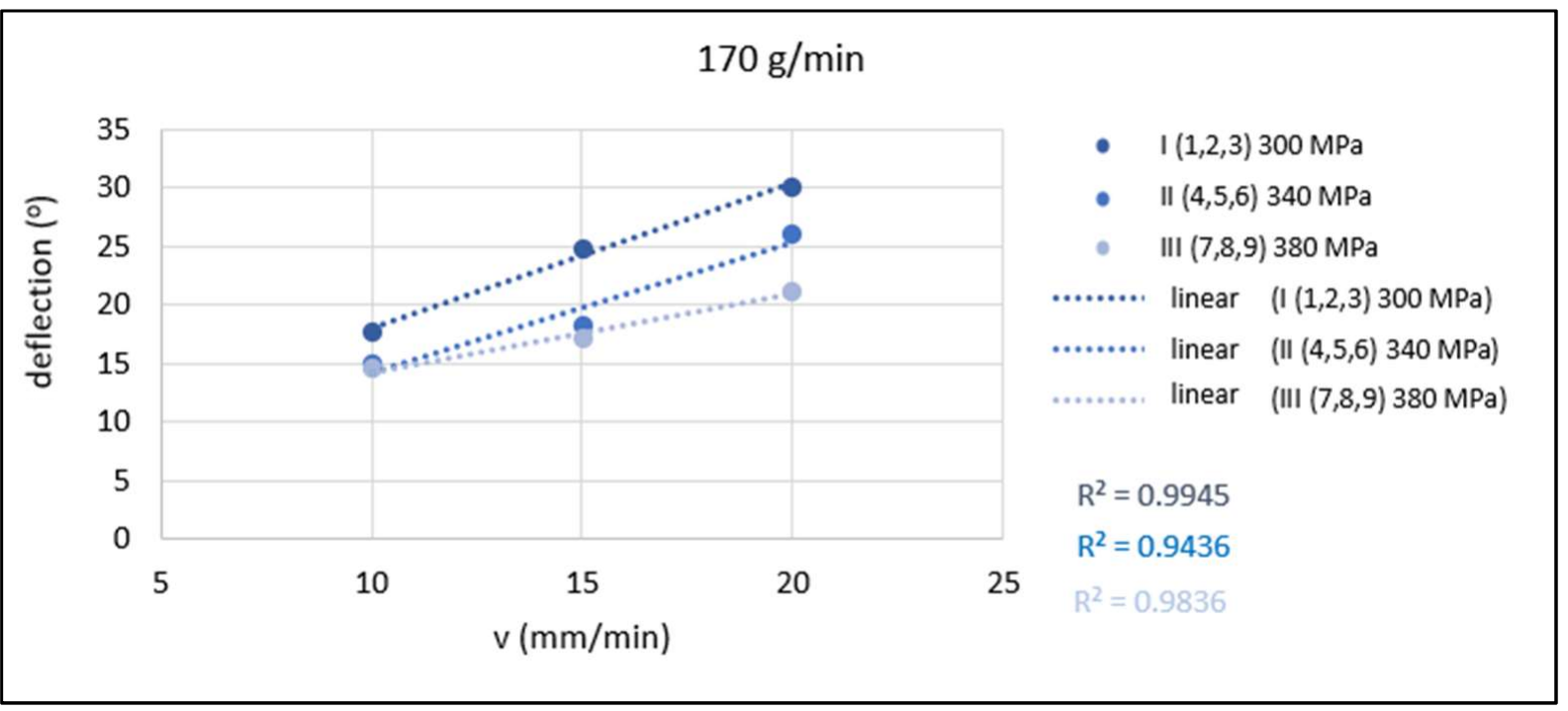

Figure 11. Cont. 

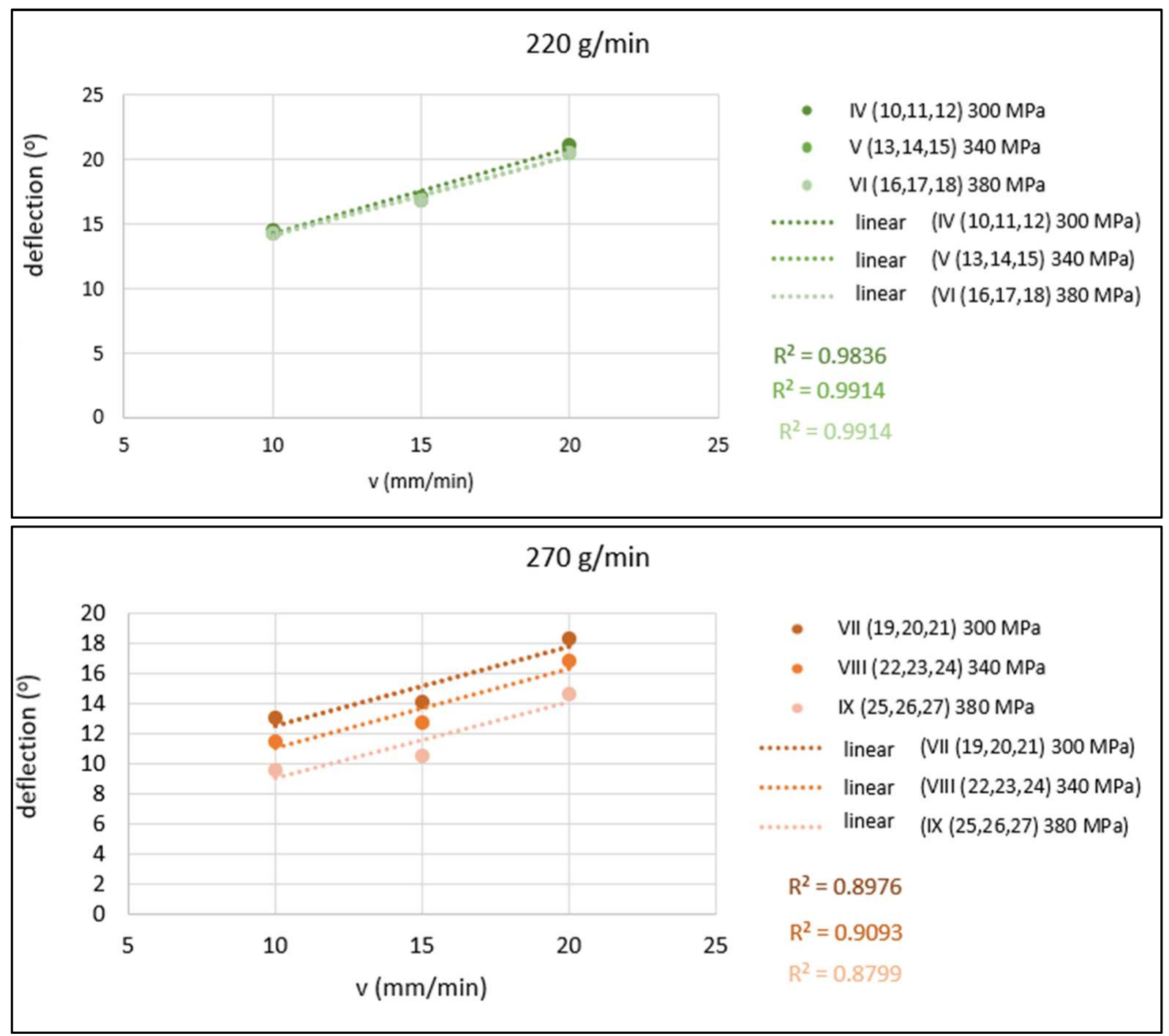

Figure 11. Graphical evaluation of 1-parametric dependencies of $\varnothing=\mathrm{f}(v)$ for $m_{A}=170,220$ and $270 \mathrm{~g} / \mathrm{min}$.

\section{Discussion}

Specifically, the values of technological parameters $m_{A}=170 \mathrm{~g} / \mathrm{min}, p=300 \mathrm{MPa}$ and $v=20 \mathrm{~mm} / \mathrm{min}$ (cut I/3) represent the combination for the highest values of the roughness parameters measured $(R a=6.95$ and $R z=24.96)$, whereas $R a$ values range from 2.27 to 6.95 and $R z$ range from 16.02 to 24.96 . The possibility to reduce the $R a$ value from 6.95 to 2.27 represents an improvement in roughness of almost $68 \%$ (approximately one third of the highest value reached).

On the other side, the values of technological parameters $m_{A}=270 \mathrm{~g} / \mathrm{min}, p=380 \mathrm{MPa}$ and $v=10 \mathrm{~mm} / \mathrm{min}$ (cut IX/25) represent the combination for the lowest roughness parameters measured $(R a=2.27$ and $R z=16.02)$. The reduction in the $R z$ value from 24.96 to 16.02 represents an improvement in roughness of almost $36 \%$.

Mathematical models describing the functional dependence of selected technological parameters $m_{A}(\mathrm{x} 1), p(\mathrm{x} 2)$ and $v(\mathrm{x} 3)$ on the quality parameters $R a(\mathrm{y})$ and $R z(\mathrm{y})$ are presented below. Figure 12 graphically indicates the significance of individual parameters. The indices of determination indicate a close approximation of the curve given by the functional dependence of the curve constructed from the evaluation of the measured values.

$$
R a \mathrm{y}=7.288-0.014 \mathrm{x}_{1}-0.009 \mathrm{x}_{2}+0.146 \mathrm{x}_{3} \quad \mathrm{R}^{2} \mathrm{u}=0.733
$$




$$
R z \mathrm{y}=28.725-0.037 \mathrm{x}_{1}-0.018 \mathrm{x}_{2}+0.348 \mathrm{x}_{3} \quad \mathrm{R}^{2} \mathrm{u}=0.942
$$
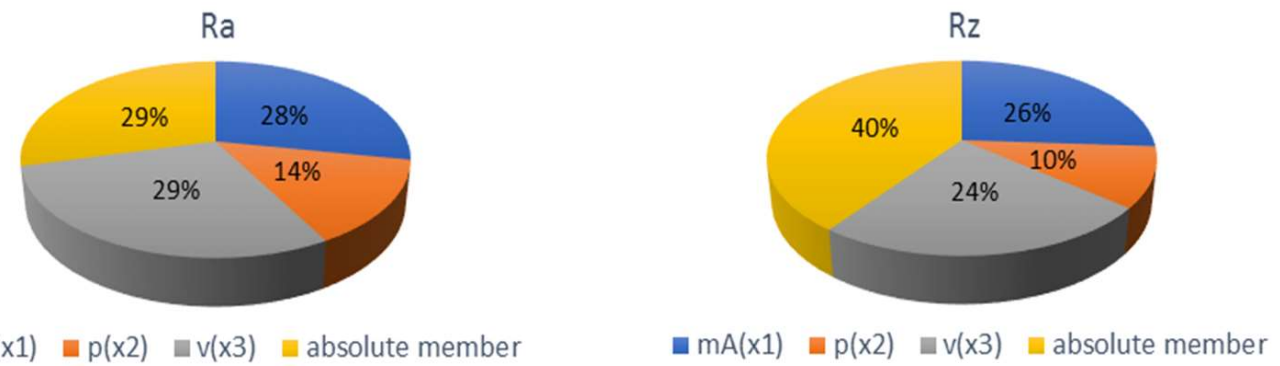

Figure 12. Graph of significance of mathematical model parameters for $R a$ and $R z$ roughness parameters.

According to the significance graphs in Figure 12, it can be stated that the greatest influence of the monitored technological parameters on the roughness parameters $R a$ and $R z$ has almost the same share as the cutting feed rate $v$ and the abrasive mass flow $m_{A}$. On the other side, the smaller influence has the pump pressure $p$. By comparing the measured values of roughness with their average values $R a=3.41$ and $R z=19.72$, it can be stated that about the same roughness $R a$ and $R z$ with deviations of 0.13 can be achieved by several combinations of technological parameters, according to Table 3. By increasing the $\mathrm{m}_{\mathrm{A}}$ from 220 to $270 \mathrm{~g} / \mathrm{min}$ at a constant pressure of $300 \mathrm{MPa}$, it is possible to cut a third more material with almost the same roughness value $R a$ of the cut surface. By increasing the $m_{A}$ from 170 to $270 \mathrm{~g} / \mathrm{min}$ at a constant $\mathrm{p}=340 \mathrm{MPa}$, it is possible to cut twice the amount of material with almost the same roughness value $R z$ of the cut surface.

Table 3. Example of combinations of values of technological parameters for achieving approximately equal (average) roughness $R a=3.41 ; R z=19.72$.

\begin{tabular}{|c|c|c|c|c|c|c|}
\hline $\begin{array}{l}\text { Combination } \\
\text { of Parameters }\end{array}$ & $\begin{array}{l}\text { Technological } \\
\text { Parameter }\end{array}$ & Value & $R a$ & $\begin{array}{c}\text { Cutting } \\
\text { Surface } \\
\text { Identification }\end{array}$ & $R z$ & $\begin{array}{c}\text { Cutting } \\
\text { Identification }\end{array}$ \\
\hline 1 & $\begin{array}{c}m_{A} \\
p \\
v\end{array}$ & $\begin{array}{c}220 \mathrm{~g} / \mathrm{min} \\
300 \mathrm{MPa} \\
15 \mathrm{~mm} / \mathrm{min}\end{array}$ & 3.46 & IV /11 & 19.79 & II $/ 4$ \\
\hline 2 & $\begin{array}{c}m_{A} \\
p \\
v\end{array}$ & $\begin{array}{c}220 \mathrm{~g} / \mathrm{min} \\
380 \mathrm{MPa} \\
20 \mathrm{~mm} / \mathrm{min}\end{array}$ & 3.46 & $\mathrm{VI} / 18$ & 19.66 & VI/17 \\
\hline 3 & $\begin{array}{c}m_{A} \\
p \\
v\end{array}$ & $\begin{array}{c}270 \mathrm{~g} / \mathrm{min} \\
300 \mathrm{MPa} \\
20 \mathrm{~mm} / \mathrm{min}\end{array}$ & 3.33 & $\mathrm{VII} / 21$ & 19.77 & VIII/24 \\
\hline
\end{tabular}

The values of technological parameters $m_{A}=170 \mathrm{~g} / \mathrm{min}, p=300 \mathrm{MPa}$ and $v=20 \mathrm{~mm} / \mathrm{min}$ represent the combination for which the highest values of roughness were achieved for $R a_{4}=3.36$ and $R z_{4}=21.69$ for $R a_{4}$ ranging from 2.02 to 3.36 and $R z_{4}$ ranging from 16.19 to 21.69 (cut I/3).

On the other side, the values of technological parameters $m_{A}=270 \mathrm{~g} / \mathrm{min}, p=380 \mathrm{MP}$ and $\mathrm{v}=10 \mathrm{~mm} / \mathrm{min}$ represent the combination for which the lowest values of roughness were achieved, that is $R a_{4}=2.02$ and $R z_{4}=16.19$ from the range of $R a_{4}<2.02 ; 3.36>$ and $R z_{4}$ $<16.19 ; 21.69>$ of the cut (I/3). It can also be stated that as the abrasive mass flow increases (from 170 to 220 and $270 \mathrm{~g} / \mathrm{min}$ ), the roughness decreases. Similarly, the roughness also decreases with increasing pump operating pressure (from 300 to 340 and $380 \mathrm{MPa}$ ). By reducing the feed rate (from 20 to 15 to $10 \mathrm{~mm} / \mathrm{min}$ ), the roughness also decreases.

Mathematical models for expressing the functional dependence of selected technological parameters $m_{A}(\mathrm{x} 1) ; p(\mathrm{x} 2)$ and $v(\mathrm{x} 3)$ on the quality parameters $R a_{4}(\mathrm{y})$ and $R z_{4}(\mathrm{y})$ are 
given below. Figure 13 shows a graphical representation of the significance of individual parameters. These indices of determination indicate an approximation of the curve given by the functional dependence to the curve constructed from the measured values.

$$
\begin{array}{ll}
R a_{4} \mathrm{y}=5.037-0.007 \mathrm{x}_{1}-0.003 \mathrm{x}_{2}+0.014 \mathrm{x}_{3} & \mathrm{R}^{2} \mathrm{u}=0.943 \\
R z_{4} \mathrm{y}=27.982-0.026 \mathrm{x}_{1}-0.013 \mathrm{x}_{2}+0.057 \mathrm{x}_{3} & \mathrm{R}_{\mathrm{u}}^{2}=0.918
\end{array}
$$
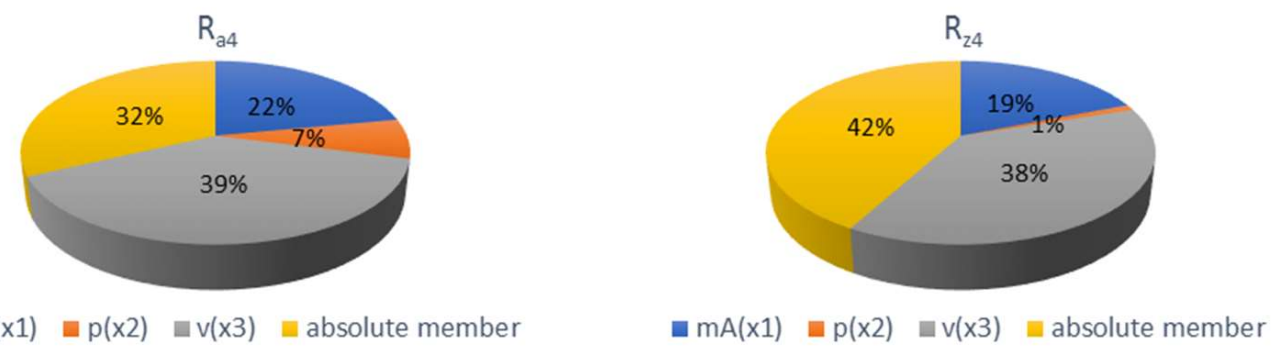

Figure 13. Graph of significance of mathematical model parameters for $R a_{4}$ and $R z_{4}$ roughness parameters.

According to the significance graphs in Figure 13, it can be stated that the greatest influence on the change in roughness values $R a_{4}$ and $R z_{4}$ has a change in the feed rate of the technological head (observed at constant abrasive mass flow and pump pressure), where the interval of variations respective to lower roughness values of $R a_{4}$ range from $1.6 \%$ to $44.8 \%$ and of $R z_{4}$ from $1 \%$ to $32.8 \%$. The second greatest effect on roughness has the value of abrasive mass flow (observed at constant pump pressure and cutting head feed rate), with an interval for the improved values ranging for $R a_{4}$ from $2.9 \%$ to $30.4 \%$ and for $R z_{4}$ from $2.3 \%$ to $19 \%$. The pump pressure (observed at constant abrasive mass flow and cutting head feed rate) has the least effect on roughness from the selected parameters, with an interval of varying values ranging for $R a_{4}$ from $0 \%$ to $18.5 \%$ and for $R z_{4}$ from $1.1 \%$ to $14.1 \%$.

By comparing the measured values of roughness with their average values of $R a_{4}=3.15$ and $R z_{4}=20.95$, it can be stated that about the same roughness $R a_{4}$ (with a variance of 0.07 ) and $R z_{4}$ (with a variance of 0.2 ) can be achieved by several combinations of technological parameters, according to Table 4 .

Table 4. Example of combinations of values of technological parameters for achieving approximately

\begin{tabular}{|c|c|c|c|c|c|c|c|c|}
\hline $\begin{array}{l}\text { Combination of } \\
\text { Parameters }\end{array}$ & $\begin{array}{c}\text { Technological } \\
\text { Parameter }\end{array}$ & Value & $R a_{4}$ & $\begin{array}{l}\text { Cutting Surface } \\
\text { Identification }\end{array}$ & $\begin{array}{c}\text { Technological } \\
\text { Parameter }\end{array}$ & Value & $R z_{4}$ & $\begin{array}{c}\text { Cutting } \\
\text { Identification }\end{array}$ \\
\hline 1 & $\begin{array}{c}m_{A} \\
p \\
v\end{array}$ & $\begin{array}{c}170 \mathrm{~g} / \mathrm{min} \\
300 \mathrm{MPa} \\
15 \mathrm{~mm} / \mathrm{min}\end{array}$ & 3.10 & $\mathrm{I} / 2$ & $\begin{array}{c}m_{A} \\
p \\
v\end{array}$ & $\begin{array}{c}170 \mathrm{~g} / \mathrm{min} \\
380 \mathrm{MPa} \\
20 \mathrm{~mm} / \mathrm{min}\end{array}$ & 19.99 & III/9 \\
\hline 2 & $\begin{array}{c}m_{A} \\
p \\
v\end{array}$ & $\begin{array}{c}170 \mathrm{~g} / \mathrm{min} \\
340 \mathrm{MPa} \\
20 \mathrm{~mm} / \mathrm{min}\end{array}$ & 3.10 & $\mathrm{II} / 6$ & $\begin{array}{c}m_{A} \\
p \\
v\end{array}$ & $\begin{array}{c}170 \mathrm{~g} / \mathrm{min} \\
340 \mathrm{MPa} \\
20 \mathrm{~mm} / \mathrm{min}\end{array}$ & 21.39 & II / 6 \\
\hline 3 & $\begin{array}{c}m_{A} \\
p \\
v\end{array}$ & $\begin{array}{c}170 \mathrm{~g} / \mathrm{min} \\
300 \mathrm{MPa} \\
10 \mathrm{~mm} / \mathrm{min}\end{array}$ & 3.03 & $\mathrm{I} / 1$ & $\begin{array}{c}m_{A} \\
p \\
v\end{array}$ & $\begin{array}{c}220 \mathrm{~g} / \mathrm{min} \\
300 \mathrm{MPa} \\
20 \mathrm{~mm} / \mathrm{min}\end{array}$ & 19.95 & $\mathrm{IV} / 12$ \\
\hline
\end{tabular}
equal (average) roughness $R a_{4}=3.15 ; R z_{4}=20.95$.

The values of technological parameters $m_{A}=170 \mathrm{~g} / \mathrm{min}, p=300 \mathrm{MPa}$ and $v=20 \mathrm{~mm} / \mathrm{min}$ represent a combination for which the worst qualitative parameter value was achieved, whereas the deflection of the abrasive water jet was observed at $\varnothing=30.1^{\circ}$, ranging from $9.6^{\circ}$ to $30.1^{\circ}$ (cut I/3). The values of technological parameters $m_{A}=270 \mathrm{~g} / \mathrm{min}, p=380 \mathrm{MPa}$ and $v=10 \mathrm{~mm} / \mathrm{min}$ represent the combination for which the best value of the jet deflection of $\varnothing=9.6^{\circ}$ was observed, ranging from $9.6^{\circ}$ to $30.1^{\circ}$ (which means an improvement of 
$68 \%$ ) for the cut (IX/25). It can also be stated that as the cutting head feed rate decreases (from 20 to 15 and further to $10 \mathrm{~mm} / \mathrm{min}$ ), the jet deflection decreases. As the abrasive mass flow increases (from 170 to 220 up to $270 \mathrm{~g} / \mathrm{min}$ ), the jet deflection decreases. As the pump pressure increases (from 300 to 340 and $380 \mathrm{MPa}$ ), the jet deflection decreases.

The mathematical model for expressing the functional dependence of the selected technological parameters $m_{A}\left(\mathrm{x}_{1}\right), p\left(\mathrm{x}_{2}\right)$ and $v\left(\mathrm{x}_{3}\right)$ on the quality parameter represented by deflection of the abrasive water jet $\varnothing(\mathrm{y})$ is given below. Figure 14 provides a graphical representation of the significance of individual parameters. These indices of determination indicate an approximation of the curve given by the functional dependence to the curve constructed from the measured values.

$$
\varnothing \mathrm{y}=38.118-0.071 \mathrm{x}_{1}-0.048 \mathrm{x}_{2}+0.702 \mathrm{x}_{3} \quad \mathrm{R}_{\mathrm{u}}^{2}=0.873
$$

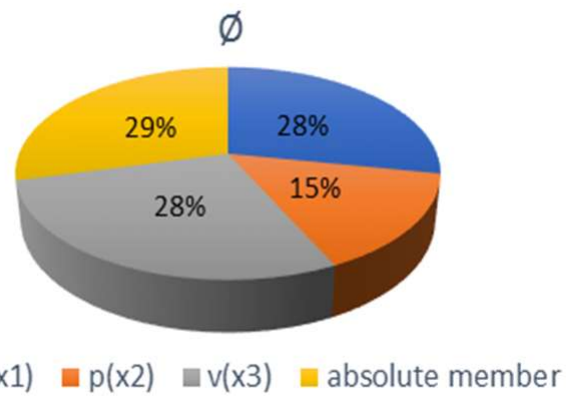

Figure 14. Graph of significance of mathematical model parameters for deflection $\varnothing$.

Based on the differences of the specific measured values of the jet deflection at the mutual concurrent influence of the monitored technological parameters $\left(m_{A}, p\right.$ and $\left.v\right)$, and according to the graph of significance in Figure 14, it can be stated that the greatest influence on the variations of jet deflection values is the change of the cutting head feed rate (observed at constant $m_{A}$ and $p$ ), where the interval of changes towards the lower jet deflection values was from $8.2 \%$ to $42.5 \%$. The second largest, which had almost the same effect on the jet deflection as the feed rate of the cutting head, has a change of the abrasive mass flow (observed at constant $p$ and $v$ ) with the change's interval towards better values, from $6.9 \%$ to $42.7 \%$. The pump pressure (observed at constant $m_{A}$ and $v$ ) has a smaller effect on the jet deflection with a variation interval of $2.4 \%$ to $30.7 \%$.

When comparing the measured values of jet deflections with their average value of $16.8^{\circ}$, it can be stated that almost the same jet deflection with a scattering of only $1.9^{\circ}$ can be achieved by several combinations of technological parameters $m_{A \min }-p_{\text {min }}{ }^{-}$ $v_{\text {min }} \sim m_{\text {Amin }}-p_{\text {max }}-v_{\text {med }} \sim m_{\text {Amed }}-p_{\text {min }}-v_{\text {med }} \sim m_{\text {Amed }}-p_{\text {med }}-v_{\text {med }} \sim m_{\text {Amax }}-p_{\text {max }}-v_{\text {max }}$ (med denotes medium value). Table 5 summarizes this more clearly with specific parameter values and measured jet deflection values.

\subsection{Recommendations for Values of Roughness $R a, R z$ and Deflection of Abrasive Water Jet $\varnothing$}

The recommended values of technological parameters for achieving the minimum and maximum experimentally measured values of roughness $R a, R z$ and $\varnothing$ are clearly summarized in Table 6. The significance of the monitored technological parameters influencing the quality of the cut surfaces is given in Table 7. 
Table 5. Combinations of technological parameter values selected from the evaluated ranges that have a similar effect to achieving approximately the same deflection of the abrasive water jet $\varnothing\left(16.8^{\circ}\right)$.

\begin{tabular}{|c|c|c|c|c|c|c|}
\hline $\begin{array}{l}\text { Combination } \\
\text { of Parameters }\end{array}$ & Min & Medium & $\operatorname{Max}$ & $\begin{array}{c}\text { Technological } \\
\text { Parameter } \\
\text { Value }\end{array}$ & Jet Deflection & $\begin{array}{c}\text { Cutting } \\
\text { Identification }\end{array}$ \\
\hline 1 & $\begin{array}{c}m_{\text {Amin }} \\
p_{\text {min }} \\
v_{\text {min }} \\
\end{array}$ & & & $\begin{array}{c}170 \mathrm{~g} / \mathrm{min} \\
300 \mathrm{MPa} \\
10 \mathrm{~mm} / \mathrm{min}\end{array}$ & $17.7^{\circ}$ & $\mathrm{I} / 1$ \\
\hline 2 & $m_{\text {Amin }}$ & $v_{\text {med }}$ & $p_{\max }$ & $\begin{array}{c}170 \mathrm{~g} / \mathrm{min} \\
380 \mathrm{MPa} \\
15 \mathrm{~mm} / \mathrm{min}\end{array}$ & $17.1^{\circ}$ & $\mathrm{III} / 8$ \\
\hline 3 & $p_{\text {min }}$ & $\begin{array}{c}m_{\text {Amed }} \\
v_{\text {med }}\end{array}$ & & $\begin{array}{c}220 \mathrm{~g} / \mathrm{min} \\
300 \mathrm{MPa} \\
15 \mathrm{~mm} / \mathrm{min}\end{array}$ & $16.9^{\circ}$ & IV/11 \\
\hline 4 & & $\begin{array}{c}m_{\text {Amed }} \\
p_{\text {med }} \\
v_{\text {med }}\end{array}$ & & $\begin{array}{c}220 \mathrm{~g} / \mathrm{min} \\
340 \mathrm{MPa} \\
15 \mathrm{~mm} / \mathrm{min}\end{array}$ & $15.8^{\circ}$ & $\mathrm{V} / 14$ \\
\hline 5 & & & $\begin{array}{c}m_{A \max } \\
p_{\max } \\
v_{\max }\end{array}$ & $\begin{array}{c}270 \mathrm{~g} / \mathrm{min} \\
380 \mathrm{MPa} \\
20 \mathrm{~mm} / \mathrm{min}\end{array}$ & $16.8^{\circ}$ & VIII/24 \\
\hline
\end{tabular}

Table 6. Recommended values of technological parameters for achieving minimum and maximum experimentally measured values of parameters $R a, R z$ and $\varnothing$.

\begin{tabular}{|c|c|c|c|c|c|c|c|}
\hline & \multicolumn{3}{|c|}{ Technological Parameter } & \multicolumn{4}{|c|}{ Qualitative Parameter } \\
\hline & $m_{A}$ & $p$ & $v$ & $R a$ & $R z$ & $\varnothing$ & $\begin{array}{c}\text { Quality (Surface } \\
\text { Roughness), Application }\end{array}$ \\
\hline $\begin{array}{l}\text { for minimum } \\
\text { measured values }\end{array}$ & $270 \mathrm{~g} / \mathrm{min}$ & $380 \mathrm{MPa}$ & $\begin{array}{c}10 \\
\mathrm{~mm} / \mathrm{min}\end{array}$ & 2.27 & 16.02 & $9.6^{\circ}$ & $\begin{array}{c}\text { low roughness, } \\
\text { without/easy further } \\
\text { processing }\end{array}$ \\
\hline $\begin{array}{l}\text { for maximum } \\
\text { measured values }\end{array}$ & $170 \mathrm{~g} / \mathrm{min}$ & $300 \mathrm{MPa}$ & $\begin{array}{c}20 \\
\mathrm{~mm} / \mathrm{min}\end{array}$ & 6.95 & 24.96 & $30.1^{\circ}$ & $\begin{array}{l}\text { very high roughness, } \\
\text { material cutting }\end{array}$ \\
\hline
\end{tabular}

Table 7. Significance of technological parameters influencing the quality of the cut surface.

\begin{tabular}{|c|c|c|c|c|}
\hline \multirow[b]{2}{*}{$\begin{array}{l}\text { Technological } \\
\text { Parameter }\end{array}$} & \multirow{2}{*}{$\begin{array}{l}\text { Significance of the } \\
\text { Technological } \\
\text { Parameter }\end{array}$} & \multicolumn{3}{|c|}{ Technological Conditions } \\
\hline & & $m_{A}[\mathrm{~g} / \mathrm{min}]$ & $\begin{array}{c}p \\
{[\mathrm{MPa}]}\end{array}$ & $v[\mathrm{~mm} / \mathrm{min}]$ \\
\hline $\begin{array}{c}m_{A} \\
p \\
v\end{array}$ & $\begin{array}{l}\text { High } \\
\text { Low } \\
\text { High }\end{array}$ & $170 ; 220 ; 270$ & $300 ; 340 ; 380$ & $\begin{array}{l}10 ; 15 \\
20\end{array}$ \\
\hline
\end{tabular}

\subsection{Recommendations for Roughness Values $R a_{4}$ and $R z_{4}$}

For $40 \mathrm{~mm}$ thick sheets, in order to achieve low roughness $\left(R a_{4}\right.$ about 2 and $R z_{4}$ about 16) on the cut surface at a distance of $4 \mathrm{~mm}$ from the upper cutting edge (Figure 3 ), and to achieve a small deflection of the abrasive water jet $\left(\varnothing\right.$ below $\left.10^{\circ}\right)$, it is recommended to use values of technological parameters $m_{A}=270 \mathrm{~g} / \mathrm{min}, p=380 \mathrm{MPa}$ and $v=10 \mathrm{~mm} / \mathrm{min}$. High roughness values ( $R a_{4}$ about 3.4 and $R z_{4}$ about 21.7) at a distance of $4 \mathrm{~mm}$ from the upper cutting edges is achieved at technological parameters $m_{A}=170 \mathrm{~g} / \mathrm{min}, p=300 \mathrm{MPa}$ and $v=20 \mathrm{~mm} / \mathrm{min}$. The most influential (most important) parameter for the change of roughness is the feed rate of the cutting head, followed by the mass flow of the abrasive, and the least influential parameter is the pump pressure. 


\section{Conclusions}

The article is aimed at the study of the influence of three selected technological parameters (abrasive mass flow, pump pressure and cutting/technological head feed rate on selected quality parameters of cut surfaces (surface roughness $R a, R z, R a_{4}, R z_{4}$ and jet deflection Ø)) after cutting $40 \mathrm{~mm}$ thick Hardox 500 steel sheet samples using the AWJ technological system. The presented results apply to the specific conditions of the experiments as described in the article. The obtained results of measurements and analyses allow to formulate the following conclusions:

- The most significant improvements regarding the roughness of the cut surfaces of $40 \mathrm{~mm}$ thick Hardox sheets are achieved by reducing the feed rate of the cutting head and increasing the mass flow of the abrasive. The same applies to the deflection of the abrasive water jet. Pump pressure parameter is less effective to change the roughness as well as the deflection of the abrasive water jet;

- Lower roughness values of $R a, R z, R a_{4}$ and $R z_{4}$ in the samples were caused by lower cutting feed rate, but at the same time, the highest used value of the feed rate $v=20 \mathrm{~mm} / \mathrm{min}$ can be considered as the limit if it acts in combination with the lowest values of the other two technological parameters $\mathrm{mA}$ and $\mathrm{p}$. If this limit value is exceeded, it may not be possible to perform a complete cut of the sheet;

- The feed rate of the cutting head has the greatest influence on the deflection of the jet because half the rate can compensate for the simultaneous change of mass flow and pressure from the maximum (Table 5, combination of parameters No. 5) to the level of their medium value (No. 4), as well as reduction in the feed rate from maximum (No. 3) to mean value (No. 5) compensates for the reduction in pressure from maximum to minimum and at the same time the mass flow from maximum to medium value (No. 3), as well as only the change of mass abrasive flow from maximum to minimum (No. 2). Similarly, reducing the feed rate from maximum to minimum compensates for the change in mass flow and pressure maxima (No. 5) to their minimums (No. 1). The pump pressure parameter has the least effect on the jet deflection;

- The surface quality of the upper zone of the cutting material is better than the quality of the lower zone.

- The evaluation of experiments presented in this article does not elaborate all related issues of the problems of examining the influence of selected technological parameters in terms of surface quality. It is therefore necessary to continue in this important research, especially in the context of AWJ process optimization for industrial applications. The directions of future research within the topic may comprise, for example, expanding the set of experiments for other sheet thicknesses of Hardox 500 steel or other types of Hardox steel (400, 450, 550, 600, Extreme, HiTuf or other hard-to-machine material). An alternative way is to investigate the dependence of other types of abrasive on the quality parameters of the cut surface. Finally, it could also be enwidening to research the influence of selected technological $\left(m_{A}, p, v, \ldots\right)$ and quality parameters $(R a, R z$, $\varnothing, \ldots$ ) at wider intervals of their values.

Author Contributions: Conceptualization, T.K., S.O. and M.S.; methodology, S.O. and M.S.; software, T.K. and M.S.; validation, M.S.; formal analysis, T.K. and M.S.; resources, T.K.; data curation, M.S. and T.K.; writing-original draft preparation, S.O. and M.S.; writing-review and editing, T.K.; visualization, T.K.; project administration, T.K.; funding acquisition, T.K. All authors have read and agreed to the published version of the manuscript.

Funding: This work was supported by the Slovak Ministry of Education within project VEGA No. 1/0823/21 and by the Slovak Research and Development Agency under contract No. APVV-18-0316.

Institutional Review Board Statement: Not applicable.

Informed Consent Statement: Not applicable. 
Acknowledgments: The authors would like to acknowledge prof. Stanislav Fabian for valuable comments.

Conflicts of Interest: The authors declare no conflict of interest. The funders had no role in the design of the study; in the collection, analyses, or interpretation of data; in the writing of the manuscript, or in the decision to publish the results.

\section{References}

1. Liu, X.; Liang, Z.; Wen, G.; Yuan, X. Waterjet machining and research developments: A review. Int. J. Adv. Manuf. Technol. 2019, 102, 1257-1335. [CrossRef]

2. Hashish, M. Modeling study of metal cutting with abrasive waterjets. J. Eng. Mater. Technol. Trans. ASME 1984, 106, 88-100. [CrossRef]

3. Zeng, J.; Kim, T.J. Development of an abrasive waterjet kerf cutting model for brittle materials. In Proceedings of Jet Cutting Technology; Lichtarowicz, A., Ed.; Kluwer Academic Publishers: Dordrecht, The Netherlands, 1992; pp. 483-501.

4. Kovacevic, R.; Yong, Z. Modelling of 3D abrasive waterjet machining, part 1-Theoretical basis. In Jetting Technology; Gee, C., Ed.; Mech. Eng. Pub. Ltd.: Bury St Edmunds, UK; London, UK, 1996; pp. 73-82.

5. Yong, Z.; Kovacevic, R. Modelling of 3D abrasive waterjet machining. Part 2-Simulation of machining. In Jetting Technology; Gee, C., Ed.; Mech. Eng. Pub. Ltd.: Bury St Edmunds, UK; London, UK, 1996; pp. 83-89.

6. Savkovic, B.; Kovac, P.; Dudic, B.; Gregus, M.; Rodic, D.; Strbac, B.; Ducic, N. Comparative characteristics of ductile iron and austempered ductile iron modeled by neural network. Materials 2019, 12, 2864. [CrossRef] [PubMed]

7. Hlaváč, L.M. JETCUT-Software for prediction of high-energy waterjet efficiency. In Jetting Technology; Louis, H., Ed.; Prof. Eng. Pub. Ltd.: Bury St Edmunds, UK; London, UK, 1998; pp. 25-37.

8. Chen, F.L.; Wang, J.; Lemma, E.; Siores, E. Striation formation mechanism on the jet cutting surface. J. Mater. Process. Technol. 2003, 141, 213-218. [CrossRef]

9. Henning, A.; Westkämper, E. Analysis of the cutting front in abrasive waterjet cutting. In Water Jetting; Longman, P., Ed.; BHR Group: Cranfield, UK; Bedford, UK, 2006; pp. 425-434.

10. Monno, M.; Pellegrini, G.; Ravasio, C. An experimental investigation of the kerf realised by AWJ: The influence of the pressure fluctuations. In Water Jetting; Longman, P., Ed.; BHR Group: Cranfield, UK; Bedford, UK, 2006; pp. 309-321.

11. Sutowska, M.; Kapłonek, W.; Pimenov, D.Y.; Gupta, M.K.; Mia, M.; Sharma, S. Influence of variable radius of cutting head trajectory on quality of cutting kerf in the abrasive water jet process for soda-lime glass. Materials 2020, 13, 4277. [CrossRef] [PubMed]

12. Filip, A.C.; Mihail, L.A.; Vasiloni, M.A. An experimental study on the dimensional accuracy of holes made by abrasive waterjet machining of Hardox steels. MATEC Web Conf. 2017, 137, 02003. [CrossRef]

13. Filip, A.C.; Vasiloni, M.A.; Mihail, L.A. Experimental research on the machinability of Hardox steel by abrasive waterjet cutting. MATEC Web Conf. 2017, 94, 03003. [CrossRef]

14. Hashish, M. Waterjet machining process. In Handbook of Manufacturing Engineering and Technology; Nee, A.Y.C., Ed.; Springer: London, UK, 2015.

15. Monno, M.; Ravasio, C. The effect of cutting head vibrations on the surfaces generated by waterjet cutting. Int. J. Mach. Tools Manuf. 2005, 45, 355-363. [CrossRef]

16. Servatka, M. Modelling, Simulation and Optimization of the Technological Parameters in Binding on the Demanded Quality of Products in Manufacturing Technologies with Water Jet. Ph.D. Thesis, Technical University of Košice, FMT Prešov, Slovakia, 2009. (In Slovak).

17. VDI 2906-5:1994; Quality of Cut Faces of (Sheet) Metal Parts after Cutting, Blanking, Trimming or Piercing—Fine Blanking. Verlag des Vereins Deutscher Ingenieure: Düsseldorf, Germany, 1994.

18. Mankova, I. Progressive Technologies; VIENALA: Kosice, Slovakia, 2000; pp. 63-90. ISBN 80-7099-430-4. (In Slovak)

19. Mascenik, J. Experimental determination of cutting speed influence on cutting surface character in material laser cutting. MM Sci. J. 2016, 3, 960-963. [CrossRef]

20. Mascenik, J.; Gaspar, S. Experimental assessment of roughness changes in the cutting surface and microhardness changes of the material S 355 J2 G3 after being cut by non-conventional technologies. Adv. Mater. Res. 2011, 314-316, 1944-1947. [CrossRef]

21. Wang, S.; Zhang, S.; Wu, Y.; Yang, F. Exploring kerf cut by abrasive waterjet. Int. J. Adv. Manuf. Technol. 2017, 93, 2013-2020. [CrossRef]

22. Štefek, A.; Hlaváč, L.M.; Tyč, M.; Barták, P.; Kozelský, J. Remarks to Abrasive Waterjet (AWJ) Forces Measurements. In Advances in Water Jetting. Water Jet 2019; Lecture Notes in Mechanical Engineering; Klichová, D., Sitek, L., Hloch, S., Valentinčič, J., Eds.; Springer: Cham, Switzerland, 2021. [CrossRef]

23. Deam, R.T.; Lemma, E.; Ahmed, D.H. Modelling of the abrasive water jet cutting process. Wear 2004, 257, 877-891. [CrossRef]

24. Valíček, J.; Harničárová, M.; Hlavatý, I.; Grznárik, R.; Kušnerová, M.; Hutyrová, Z.; Panda, A. Anew approach for the determination of technological parameters for hydroabrasive cutting of materials. Mater. Werkst. 2016, 47, 462-471. [CrossRef]

25. Krenicky, T. Non-contact study of surfaces created using the AWJ technology. Manuf. Technol. 2015, 15, 61-64. [CrossRef]

26. Krenicky, T.; Servatka, M.; Gaspar, S.; Mascenik, J. Abrasive Water Jet Cutting of Hardox Steels—Quality Investigation. Processes 2020, 8, 1652. [CrossRef] 
27. Nair, A.; Kumanan, S. Multi-performance optimization of abrasive water jet machining of Inconel 617 using WPCA. Mater. Manuf. Process. 2017, 32, 693-699. [CrossRef]

28. Hlaváč, L.M.; Hlaváčová, I.M.; Geryk, V.; Plančár, Š. Investigation of the taper of kerfs cut in steels by AWJ. Int. J. Adv. Manuf. Technol. 2015, 77, 1811-1818. [CrossRef]

29. Hlaváč, L.M.; Hlaváčová, I.M.; Arleo, F.; Viganò, F.; Annoni, M.; Geryk, V. Shape distortion reduction method for abrasive water jet (AWJ) cutting. Precis. Eng. 2018, 53, 194-202. [CrossRef]

30. Olejárová, Š.; Ružbarský, J.; Krenický, T. Introduction into the issue of water jet machining. In Vibrations in the Production System. SpringerBriefs in Applied Sciences and Technology; Springer: Cham, Swizerland, 2019; pp. 1-10. ISBN 978-3-030-01736-1. [CrossRef]

31. Chen, M.; Zhang, S.; Zeng, J.; Chen, B. Correcting shape error located in cut-in/cut-out region in abrasive water jet cutting proces. Int. J. Adv. Manuf. Technol. 2018, 102, 1165-1178. [CrossRef]

32. Pahuja, R.; Ramulu, M.; Hashish, M. Surface quality and kerf width prediction in abrasive water jet machining of metal-composite stacks. Compos. Part B Eng. 2019, 175, 107134. [CrossRef] 